\title{
Long-term Monitoring in Deep Boreholes in the Nankai Subduction Zone
}

by Hisao Ito

doi:10.2204/iodp.sd.s01.43.2007

\section{Introduction}

IODP NanTroSEIZE is planning to construct observatories in deep boreholes in the Nankai subduction zone to monitor interseismic behavior at and above the updip limit of seismogenic zone. The deep observatories will be at NT2-03 and NT3-01; NT2-03 will be 3.5-km deep below sea floor to penetrate several splay faults, and NT3-01 will be $6-\mathrm{km}$ deep to penetrate the splay faults and plate boundary fault.

Scientific needs for long term in situ monitoring at and near splay faults and plate boundary fault include detailed analysis of low frequency/slow events, strain partioning during interseismic period, and near-source hydrological/seismic/ geodetic observations.

\section{Scientific Needs}

A deep borehole observatory has advantages in surface noise reduction (Araki et al., 2004), high frequency recording with little attenuation, observation in the close vicinity of

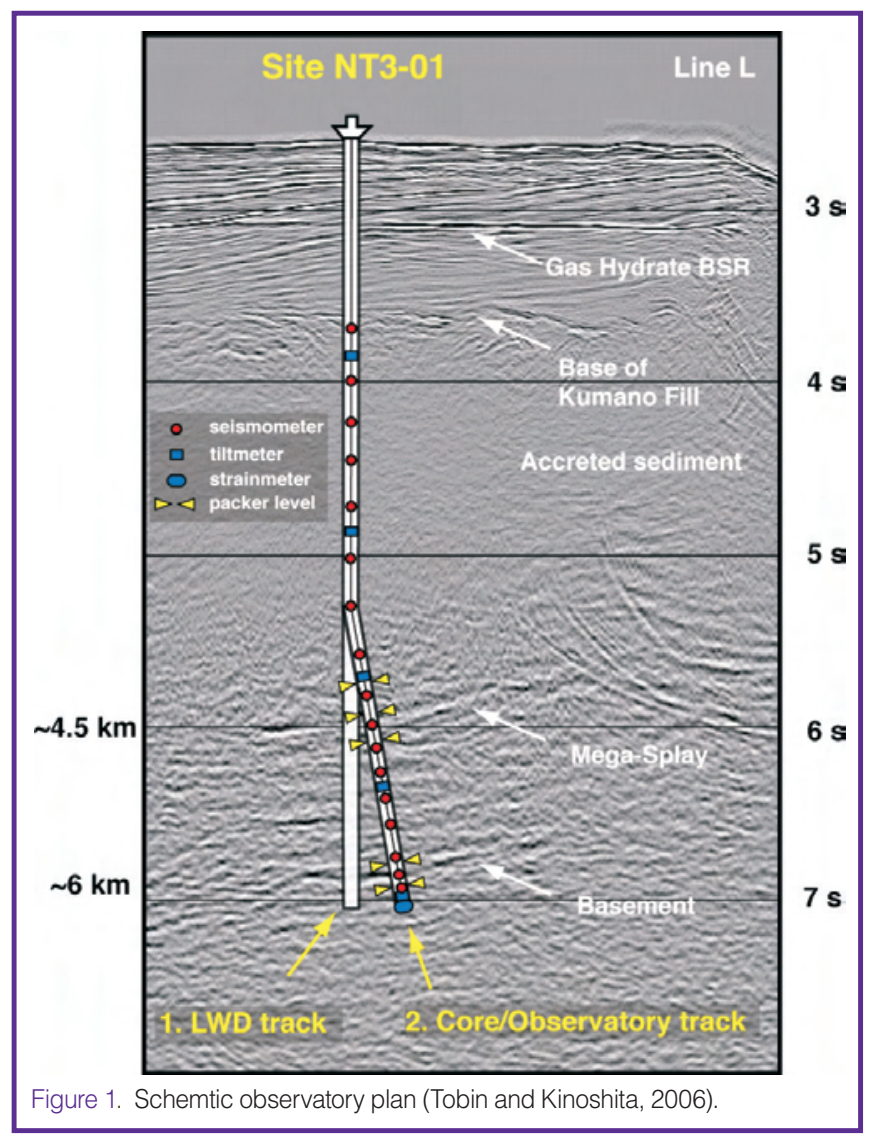

active processes, and installing a vertical sensor array along the borehole to improve the depth resolution (Chavarria et al., 2003).

Drilling through the updip limit of the fault and establishing borehole observatories is important to understand the following issues:

- Crustal deformation throughout the hanging wall to the fault zone

- How the strain caused by the backstop and subducting plate affect the fault plane strain

- Existence of any slip across the fault

- Is the fault locked? Is the fault weak?

- Correlation with asperity inferred from 3-D seismics

- Importance of mesoscopic structure for dynamic rupture

- Slow deformation in fault zone before dynamic rupture

- Structure of plate boundary/splay fault

- Occurrence of dynamic rupture in thin slip zones (main slip) and slow ductile deformation in thick fault zones.

Answers to the following questions may also be provided from a borehole observatory:

- Can both (thin slip zone and thick fault zone) occur within "asperity"?

- How thin or thick are the zones?

- How do they rupture coseismically?

- How do they deform in an interseismic period?

- How are they deforming now ?

- How different are they in plate boundary / splay fault?

NanTroSEIZE scientists proposed an observatory plan (Harold and Kinoshita, 2006; Shinohara et al., 2003). One of the most essential parts of the basic idea is a distributed, multi-level multi-sensor system (Fig. 1), with seismometer, tiltmeter, strainmeter, and pressure sensors.

\section{Possible Plan}

Based on this basic concept, we have been working on a possible plan for sensors, a downhole telemetry system, a sensor/downhole telemetry system interface, and system installation. We understand that distributed sensors are essential. Currently, strain and pressure sensors need to be 
set at the bottom of the hole, and tilt/seismic/temperature monitors may be set at bottom- and mid-hole sections (Fig. 2).

\section{Major Technical Challenges}

The following major technical issues for developing a deep borehole observatory in IODP are recognized:

1. Great depths telemetry, sensor, etc.

2. High temperatures $\left(80^{\circ} \mathrm{C}-100^{\circ} \mathrm{C}\right.$ for $3.5 \mathrm{~km}$, $170^{\circ} \mathrm{C}-180^{\circ} \mathrm{C}$ for $\left.6 \mathrm{~km}\right)$

3. Long-term reliability and stability

4. Coupling of the sensors to the for mation/casing

5. Geodetic/seismic and pore pressure measurements at multiple intervals (multi-packer vs. multi-hole?)

6. Vertical drilling and core sampling at the fault interval

7. Broadband high dynamic range and high resolution recording

8. Deployment

9. Telemetry system through Christmas tree/wellhead system of riser drill holes

10. Real time monitoring through seafloor cables

\section{Borehole Telemetry System}

The system should be reliable and work for many years at high temperatures. At the same time, the system should be able to deliver data that scientists need. The system should be able to be deployed practically and maintained with reasonable efforts. The fundamental requirements may be summarized as follows: reliability, long mean-time-beforefailure (MTBF), redundancy, protection from failure, high dynamic range, continuous recording, low power consumption, and limited number of connections through pressure controlled well head/Christmas tree.

The system consists of three sections: 1) a downhole module array that digitizes seismic signals continuously and transmits the data to a recorder on sea floor, 2) a subsea recorder that receives data from downhole and stores data, and 3) a communications unit that sends commands from sea surface to the subsea recorder to check the status of the downhole systems and receives QC data (Fig. 3).

The downhole module can also send data from other sensors (e.g., pressure, temperature, and strain monitors) interfaced to auxiliary channels at a lower sampling rate.

\section{Sensor Development}

Sensors/sensor housing/connectors should be developed to work under high temperatures and great depth/hostile installation conditions.

We must carefully consider sensor installation in deep boreholes and at multi-levels. Strainmeters have to be cemented in open hole sections of the borehole. Tiltmeters

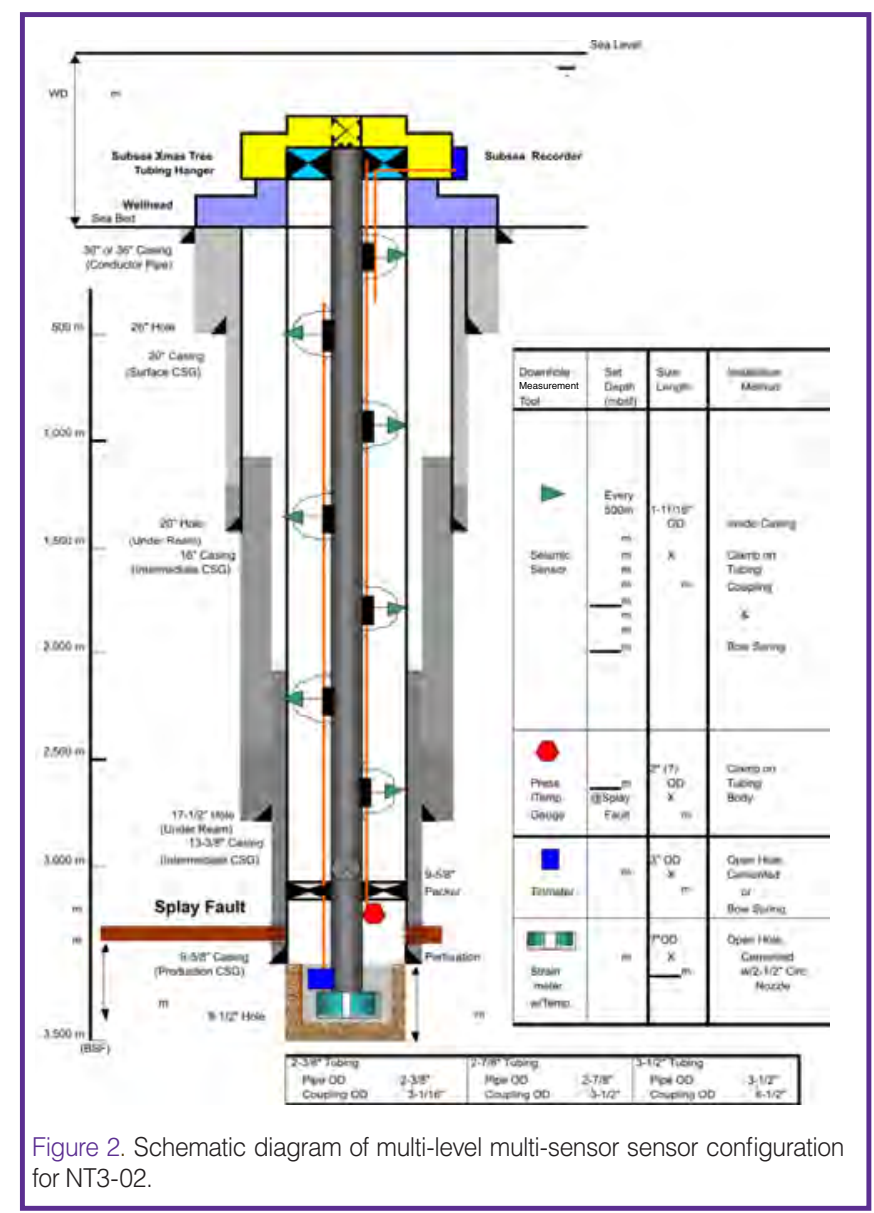

and seismometers might be cemented, however for multilevel installations we need to consider installing them by other methods (e.g., by locking arm or bow spring).

Pore pressure monitoring is useful as a proxy of strain and pore pressure variation along the fault (Davis et al., 2006; Kano and Yanagidani, 2006). To be useful as a proxy for strain, the compliance of the pressure measurement system needs to be extremely small. For monitoring pore pressure of the fault, the gault must be isolated from other sections of the borehole either by packer or cementing.

\section{Links to Shallow Boreholes/ Land Stations}

The NanTroSEIZE deep borehole observatories, which will deploy vertical array sensor systems, will be linked to a sea floor cable network and NanTroSEIZE shallow borehole observatories to be integrated to three dimensional ocean observatories. The IODP NanTroSEIZE observatories will be situated at/around the updip limit. Ideally, the IODP NanTroSEIZE observatories would also be integrated with on-land observatories, which would be above the asperities.

\section{Possible Application to Other Projects}

The telemetry system and sensors that have been developed for NanTroSEIZE will be applied in other deep boreholes, such as Costa Rica Seismogenesis Project CRISP (Ranero et al., this issue), and also The Kanto Asperity 


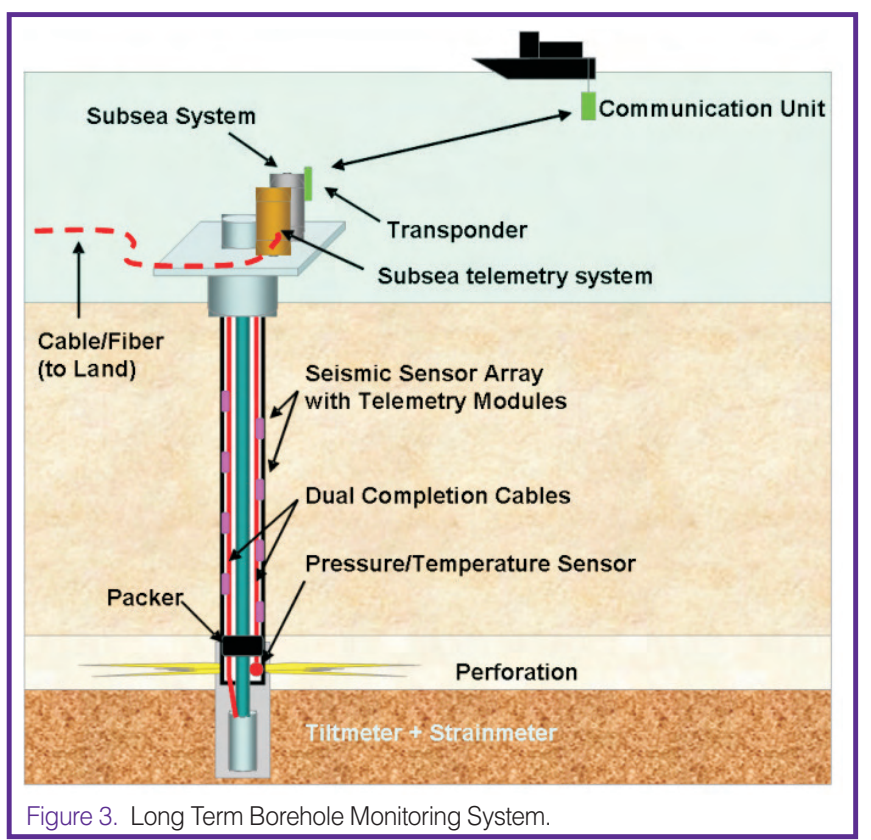

Project (KAP): KAP is a linked offshore/onshore regional geodetic and seismic network covering the asperity and nonasperity areas of the Kanto Region (Kobayashi et al., 2007). In the KAP, it is proposed to monitor strain, tilt, uplift and seismicity in the area underlain by asperities. This will show the relationship between plate motion, strain accumulation, and earthquake mode.

\section{References}

Araki, E., Shinohara, M., Sacks, S., Linde, A., Kanazawa, T., Shiobara, H., Mikada, H., and Suyehiro, K., 2004. Improvement of seismic observation in the ocean by use of seafloor boreholes. Bull. Seismol. Soc. Amer., 94:678-690, doi:10.1785/0120020088.

Chavarria, J.A., Malin, P.E., and Shalev, E. 2004. The SAFOD Pilot Hole seismic array: Wave propagation effects as a function of sensor depth and source location. Geophys. Res. Lett., 31: L12S07, doi:10.1029/2003GL019382.

Davis, E., Becker, K., Wang, K., Obara, K., Ito, Y., and Kinoshita, M., 2006. A discrete episode of seismic and aseismic deformation of the Nankai trough subduction zone accretionary prism and incoming Philippine Sea plate. Earth Planet. Sci. Lett., 242:73-84, doi:10.1016/j.epsl.2005.11.054.

Kano, Y. and Yanagidani, T. 2006. Broadband hydroseismograms observed by closed borehole wells in the Kamioka mine, central Japan: Response of pore pressure to seismic waves from 0.05 to 2 Hz.J. Geophys. Res., 111:B03410, doi:10.1029/ 2005JB003656.

Kobayashi, R., Nakao, S., Nishimura, T., Curewitz, D., Matsu'ura, M., Sagiya, T., Satake, K., Ito, T., Stein, R., Malin, P., Shalev, E., Stephen, R., Sato, T., Mochizuki, K., Hori, T., Kamiya, S. and Naka, S., 2007. Kanto Asperity Project network: a wide geodetic and seismic network covering Kanto asperity and non-asperity regions, IODP CDP proposal \#723, http:// www.iodp.org/index.php?option=com_docman\&task $=\mathrm{doc}_{-}$ download\&gid $=1550$.
Shinohara, M., Araki, E., Kamata, M., Kinoshita, M., Kyo, N., Kuroki, K., Kosuge, Y., Kobayashi, S., Konno, S., Goto, T., Saito, S., Suzuki, M., Takahashi, T., Tadokoro, K., Tsunogai, U., Tezuka, K., Nanba, K., Nishi, M., Hino, R., Mikada, H., Morita, N., Yoshida, C., and Ito, H., 2003. Long-term monitoring using deep seafloor boreholes penetrating the seismogenic zone. Bull. Earthquake Res. Inst. Univ. Tokyo, 78:205-218.

Tobin, H.J., and Kinoshita, M., 2006. NanTroSEIZE: The IODP Nankai Trough Seismogenic Zone Experiment. Sci. Drill., 2:23-27.

Tobin, H. and Kinoshita, M., 2007. Report on NanTroSEIZE LongTerm Observatories Workshop, July 17-19, 2006, San Jose and Parkfield, California.

\section{Author}

Hisao Ito, Center for Deep Earth Exploration (CDEX), Japan Agency for Marine-Earth Science and Technology (JAMSTEC), 3173-25 Showa-machi, Kanazawa-ku, Yokohama, Kanagawa 236-0001, Japan, e-mail: hisaoito@ jamstec.go.jp. 